\title{
Reduced hydraulic model of Forquilha IV tailings dam
}

\section{Modelo hidráulico reduzido da barragem de rejeitos Forquilha IV}

\begin{abstract}
This paper presents the development of a reduced hydraulic model (RHM) for the outflow operating system at the Forquilha IV (scale 1:10) tailings dam, owned by Vale S.A. The studies were performed by Centro de Pesquisas Hidráulicas e Recursos Hídricos (CPH) of Universidade Federal de Minas Gerais (UFMG) and the company Vogbr Recursos Hídricos \& Geotecnia Ltda. We present here a brief description of the model construction and the test battery set for the structure's hydraulic analysis. RHM involves the hillside culvert, the dissipation box and the exit to the restitution tunnel. The RHM project represents an essential step in the first analysis of the hydraulic behavior of the prototype, considering the designed flood station (ten thousand-year flood flow), as well as the analysis of its operation with more frequent flows.
\end{abstract}

Keywords: Reduced hydraulic model; tailing dam

\section{Resumo}

Esse trabalho apresenta o desenvolvimento de um modelo hidráulico reduzido (MHR) do sistema extravasor operacional da barragem de rejeitos Forquilha IV (escala 1:10), de propriedade da Vale S.A. Os estudos foram conduzidos pelo Centro de Pesquisas Hidráulicas e Recursos Hídricos (CPH) da Universidade Federal de Minas Gerais (UFMG) e pela empresa Vogbr Recursos Hídricos \& Geotecnia Ltda. É apresentada, nesse trabalho, uma breve descrição da construção do modelo, bem como a bateria de ensaios prevista para análise hidráulica da estrutura. O MHR representa a galeria de encosta, a caixa de dissipação e a saída para o túnel de restituição. O projeto do MHR representa uma etapa vital na análise preliminar do comportamento hidráulico do protótipo frente à passagem da cheia de projeto (vazão decamilenar), assim como a análise de seu funcionamento para vazões mais frequentes.

Palavras-chave: modelo hidráulico reduzido; barragem de rejeitos

\author{
Carlos Barreira Martinez \\ Professor Associado IV \\ Universidade Federal de Minas Gerais, \\ Escola de Engenharia - Hidráulica \\ Belo Horizonte - Minas Gerais - Brasil \\ martinez@cce.ufmg.br
}

\section{Introduction}

According to Oliveira (2010), based on terms established by Brazilian Standard $\quad$ (NBR) 13028 (2006), a tailings dam is 
"every structure that forms a wall to contain disposal" and that, considering the disposition of the materials, "stores the tailings inside the reservoir in a planned, designed and controlled way." Wrapping tailings reservoirs confined by dams are the most common form of disposal. These dams usually run from a starting dike, made of compact rockfill or embankment with successive raisings, which are performed using the tailings as construction material.

These dams in Brazil came from

\section{The place in study}

Forquilha IV tailings dam is being built in the area of Mina de Fábrica, in the city of Ouro Preto, Minas Gerais. The reservoir of the dam will be capable of storing a volume of approximately 35 $\mathrm{Mm}^{3}$ tailings. Its operation is scheduled to start in 2014 and will be performed in four major steps: a) starting dike (in compacted soil), height of about $20 \mathrm{~m}, \mathrm{~b}$ ) initial dam (also in compacted landfill), height of about $45 \mathrm{~m}, \mathrm{c}$ ) implementation mining activities, which date back about 300 years ago (CBDB, 2012). However, in recent decades, especially with the progress of mining activities, increased operational scale and the development of new techniques for mining at even low mineral levels, the production of waste to be disposed of in the environment has increased significantly. Thus, the deployment of dams increasing both in relation to height and reservoir volume for tailings has become a reality. These large dams, besides the difficulties inherent to the con- struction of massif, also have challenges in the design of their components, such as operational and final outflow systems, and their hydraulic energy dissipation structures. There are several references showing criteria for hydraulic design of dam spillways and energy dissipators for multiple water uses, including Chow (1959), USBR (1987), Hager (1992), Sinniger and Hager (1989). However, there are no studies showing criteria for the hydraulic design of operational outflow systems of tailings dams with successive raisings. of outflow operating system (object of reduced hydraulic model presented in this work) and d) 7 raising dams of 10 $\mathrm{m}$ each, using tailings as construction material (the outflow operating system will serve this step, and the project is already in operation).

The operational outflow system has the following structural components: 1) hillside culvert, made of 13 towers for water intake and the gallery

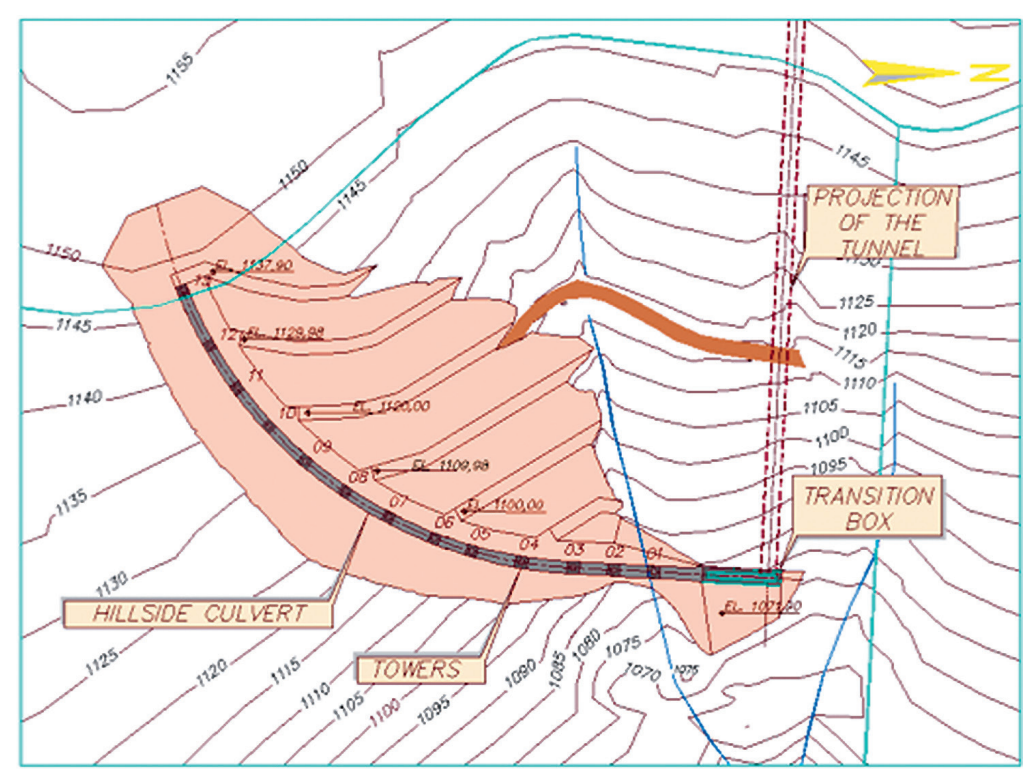

itself, 2) transition box, which has the purpose of hydraulic energy dissipation and restitution of the flow to the tunnel, 3) exit tunnel; 4) dissipation basin, which will aim to dissipate the stream energy before returning it to the thalweg adjacent to the reservoir of the Forquilha IV dam. Figure 1 shows the general arrangement of the Forquilha IV dam's outflow operating system, highlighting its structural components.
Figure 1

Overall arrangement of Forquilha IV dam outflow system operation

\section{Materials and methods}

The reduced hydraulic model for the outflow operating system of the tailings from the Forquilha IV dam was executed using a geometric scale

$$
\frac{L_{p}}{L_{m}}=\lambda
$$

Where: $\lambda$ is the ratio of the geometric dimensions between the prototype $(\mathrm{p})$ and the model $(\mathrm{m})$ in meters; of 1:10, considering the recommendations proposed by Lopardo (1986) and Teixeira (2008).

The scale for translating the results
(3) for the prototype obeyed Froude's Law (equality of Froude's Number with the prototype model), which is ruled by the following relationships:
$L_{p}$ and $L_{m}$ are the lengths (m); $V$ and $V_{m}$ are the velocities $(\mathrm{m} / \mathrm{s})$; $\mathcal{Q}_{p}$ and $\mathscr{Q}_{m}^{m}$ are the flows $\left(\mathrm{m}^{3} / \mathrm{s}\right)$
(4) $\frac{P_{p}}{P_{m}}=\lambda$ $q_{p}$ and $q_{m}$ qm are the specific flow rates $\left(\mathrm{m}^{2} / \mathrm{s}\right)$;

$P_{p}$ and $P_{m}$ are the pressures (m.c.a.). 
The reduced hydraulic model represents the hillside culvert, more precisely, the 6 towers located downstream (as shown in Figure 2), the transition box and the restitution of the flow to

Figure 2

Hillside culvert

represented in the reduced model.

The dimensions of the hillside culvert, for the transition box (prototype), and the physical model (including the tow-

Table 1

Geometric characteristics of hillside culvert

Importantly, the exit tunnel was not part of the system that makes up the reduced physical model.

Thus, only its mouth was patterned, positioned in the sidewall of the the exit tunnel.

The representation of these 6 towers more downstream is due to the fact that in a span of approximately $70 \mathrm{~m}$ of descending steps (prototype value), according to the methodology proposed by Matos (1999), the flow reaches maximum power dissipation and uniformity of aerated blade (air + water).

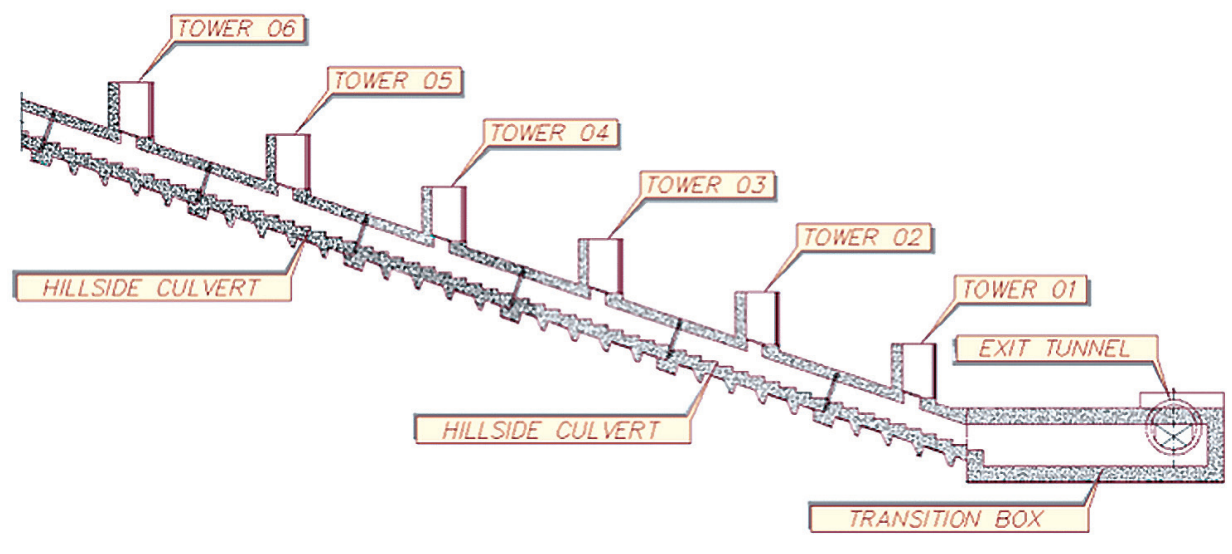

ers for water intake) have the geometrical characteristics presented in Table 1.

The purpose of the transition box is to dissipate the energy from the flow of the hillside culvert and direct it to the exit tunnel.

\begin{tabular}{|c|c|c|c|}
\hline \multirow{4}{*}{ Hillside culvert } & Characteristic & Model & Prototype \\
\hline & Internal section & $\begin{array}{c}\text { Rectangular } \\
(15 \mathrm{~cm} \times 18 \mathrm{~cm})\end{array}$ & $\begin{array}{c}\text { Rectangular } \\
(1.5 \mathrm{~m} \times 1.8 \mathrm{~m})\end{array}$ \\
\hline & Extension & $\cong 9 \mathrm{~m}$ & $\cong 90 \mathrm{~m}$ \\
\hline & Elevation & $\cong 3.5 \mathrm{~m}$ & $\cong 35 \mathrm{~m}$ \\
\hline \multirow{4}{*}{ Water intake towers } & Characteristic & Model & Prototype \\
\hline & Quantity & 06 & 06 \\
\hline & $\begin{array}{l}\text { Internal section } \\
\text { (throttle section) }\end{array}$ & $\begin{array}{c}\text { Square } \\
(15 \mathrm{~cm} \times 15 \mathrm{~cm})\end{array}$ & $\begin{array}{c}\text { Square } \\
(1.5 \mathrm{~m} \times 1.5 \mathrm{~m})\end{array}$ \\
\hline & Altura & $50 \mathrm{~cm}$ & $5.0 \mathrm{~m}$ \\
\hline \multirow{3}{*}{ Transition box } & Characteristic & Model & Prototype \\
\hline & Internal section & $\begin{array}{c}\text { Rectangular } \\
(15 \mathrm{~cm} \times 41 \mathrm{~cm})\end{array}$ & $\begin{array}{c}\text { Rectangular } \\
(1.5 \mathrm{~m} \times 4.1 \mathrm{~m})\end{array}$ \\
\hline & Extension & $2.15 \mathrm{~m}$ & $21.5 \mathrm{~m}$ \\
\hline
\end{tabular}

transition box.

It was then possible to verify the possible occurrence of drowning, even with the passage of flows from the outflow operating system design. The model consists of a passage in an opening 35 $\mathrm{cm}$ wide by $25 \mathrm{~cm}$ (model values), in an U-shaped section. Figure 3 shows a detail of the water intake tower to be installed in this outflow system. 


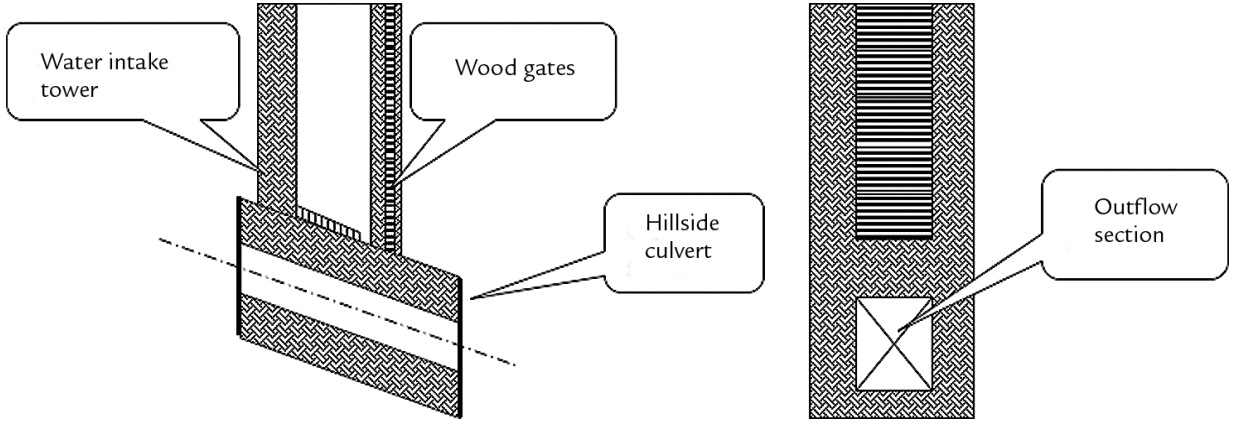

For the hydraulic dimensioning of the outflow system, in the design phase, we considered the assumptions that control would be made by the towers and water

Where: $Q$ is the flow spilled $\left(\mathrm{m}^{3} / \mathrm{s}\right)$, $C_{d}$ is the discharge coefficient $\left(\mathrm{m}^{0,5} / \mathrm{s}\right)=1.7$ (adopted value presented by

The model was constructed of wood, supported by a metal frame.

The connection of the model to the water supply system was made using flexible hoses connected to intake and that the structure would work in a free-flow situation.

Thus, for determining the discharge curve, both for the passage of the flow

$$
Q=C_{d} \cdot L \cdot H^{1,5}
$$

Azevedo Netto and Alvarez, 1988, and, Porto, 1998),

$H$ is the hydraulic head (m),

centrifugal pumps, controlled by frequency inverters.

The wood waterproofing was made with SikaTop (consisting of a coating, semi-flexible, impermeable,
Figure 3

Detail of the water intake tower (built into the hillside culvert).

from only the sides of a tower as in the situation of restitution through two towers (flow input plus the side input from the upstream tower).

$L$ is the sill width (m).

protective, and based on cement, sand and selected acrylic resin). Figures 4 to 7 show stages of construction of the reduced model of the outflow system of Forquilha IV dam.
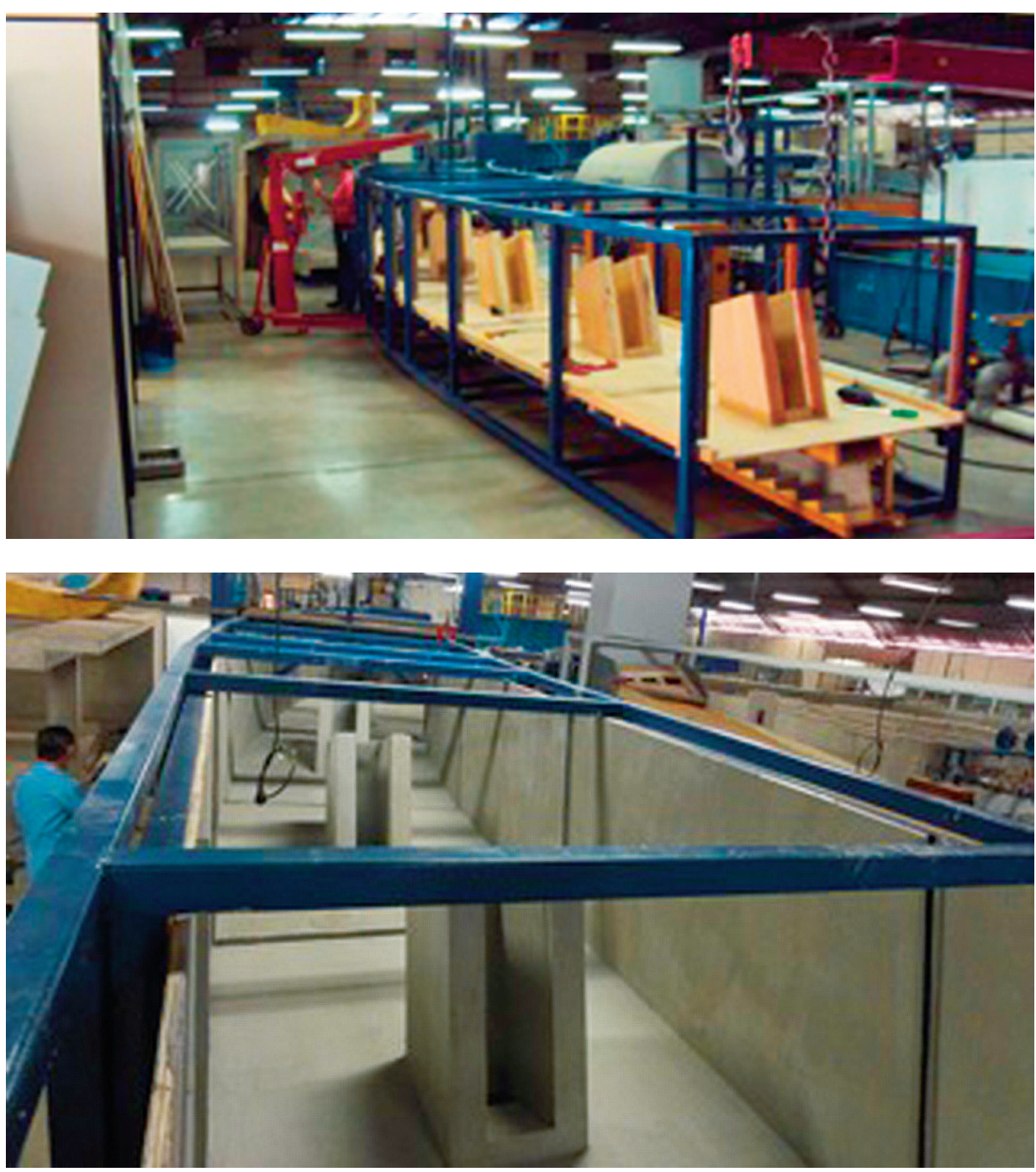

Figure 4

Hillside culvert surrounded by metal framework that will support the structure for the reduced model

Figure 5

Water reservoir and towers already waterproofed with SikaTop. 
Figure 6

Hillside culvert connected to the outlet pipe

Figure 7

Front view of hillside culvert and reservoir

\section{Tests}

The outflow operating system for the Forquilha IV dam has been designed for the passage of a ten thousand-year flood (flow rate $25 \mathrm{l} / \mathrm{s}$, corresponding to the model value).

The tests for the reduced physical model of Forquilha IV's outflow system are described below.

Table 2

Test battery for incoming flow from the sides of the towers
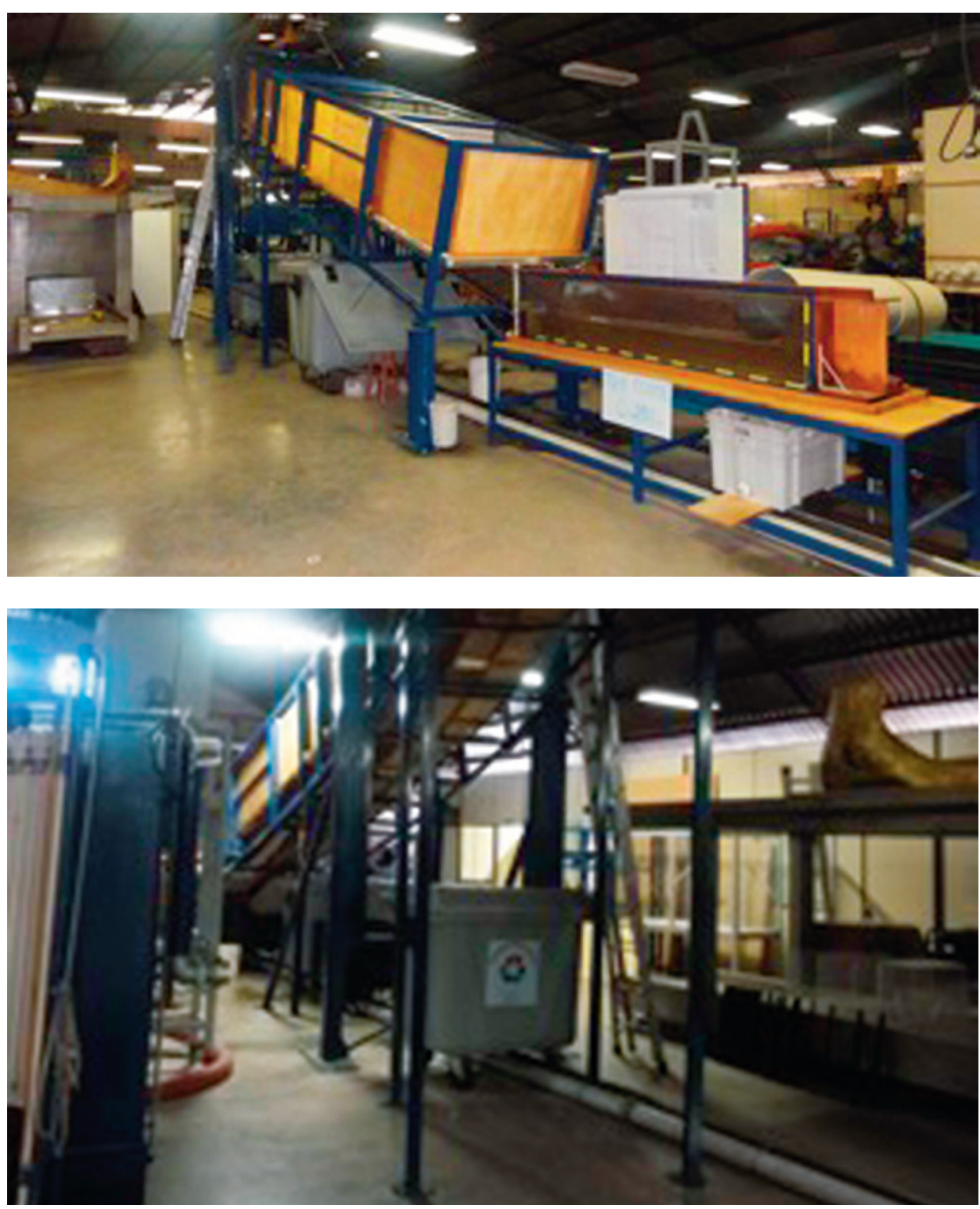

1. Tests to verify the discharge curve given the floodwater being restored only by the sides of a tower's outlet water. Situations in which flooding occurs from towers 01,02 and 05 are demonstrated in Table 2.

2. Tests to verify the discharge curve ( 7 flows, including full project) of the outflow operating system, whereby at first the floodwater was restituted by tower 01 (entrance by the sill) and 02 (side entrance), afterwards by towers 02 and 03 and, in sequence, by towers 05 and 06 , the latter being located further upstream. Table 3 presents a summary of the testing for this situation.

\begin{tabular}{c|c|c|c}
\multirow{2}{*}{ Test } & $\begin{array}{c}\text { Flow } \\
\left.\text { (prototype values }-\mathrm{m}^{3} / \mathrm{s}\right)\end{array}$ & $\begin{array}{c}\text { Flow } \\
(\text { model values }-\mathrm{l} / \mathrm{s})\end{array}$ & Total of tests \\
\hline \multirow{5}{*}{ Towers 01; 02; 05 } & 0.95 & 3 & 3 \\
\cline { 2 - 4 } & 1.58 & 5 & 3 \\
\cline { 2 - 4 } & 3.16 & 10 & 3 \\
\cline { 2 - 4 } & 4.74 & 15 & 3 \\
\cline { 2 - 4 } & 6.32 & 20 & 3 \\
\cline { 2 - 4 } & $7.91^{*}$ & $25^{*}$ & 21 \\
\hline Total of tests & 9.49 & 30 & 3 \\
\hline
\end{tabular}

* Flow rate corresponding to a ten thousandyear flood. 


\begin{tabular}{c|c|c|c}
\multicolumn{1}{c|}{ Tests } & $\begin{array}{c}\text { Flow } \\
\left.\text { (prototype values }-\mathrm{m}^{3} / \mathrm{s}\right)\end{array}$ & $\begin{array}{c}\text { Flow } \\
\text { (model values }-\mathrm{l} / \mathrm{s})\end{array}$ & Total of tests \\
\hline \multirow{4}{*}{$\begin{array}{c}\text { Towers 01 and 02; 02 } \\
\text { and 03; 05 and 06 }\end{array}$} & 0.95 & 3 & 3 \\
\cline { 2 - 4 } & 1.58 & 5 & 3 \\
\cline { 2 - 4 } & 3.16 & 10 & 3 \\
\cline { 2 - 4 } & 4.74 & 15 & 3 \\
\cline { 2 - 4 } & 6.32 & 20 & 3 \\
\cline { 2 - 4 } & $7.91^{*}$ & $25^{*}$ & 3 \\
\hline \multicolumn{2}{|c}{ Total of tests } & 30 & 21 \\
\hline
\end{tabular}

* Flow rate corresponding to a ten thousand year floodwater.

Figures 8 to 10 show passage of the ten thousand-year floodwater, considering outflow through the sill of tower 02 and

side of tower 03 , simultaneously.

In Tables 2 and 3, the hydraulic flow discharge values on the tower sill and
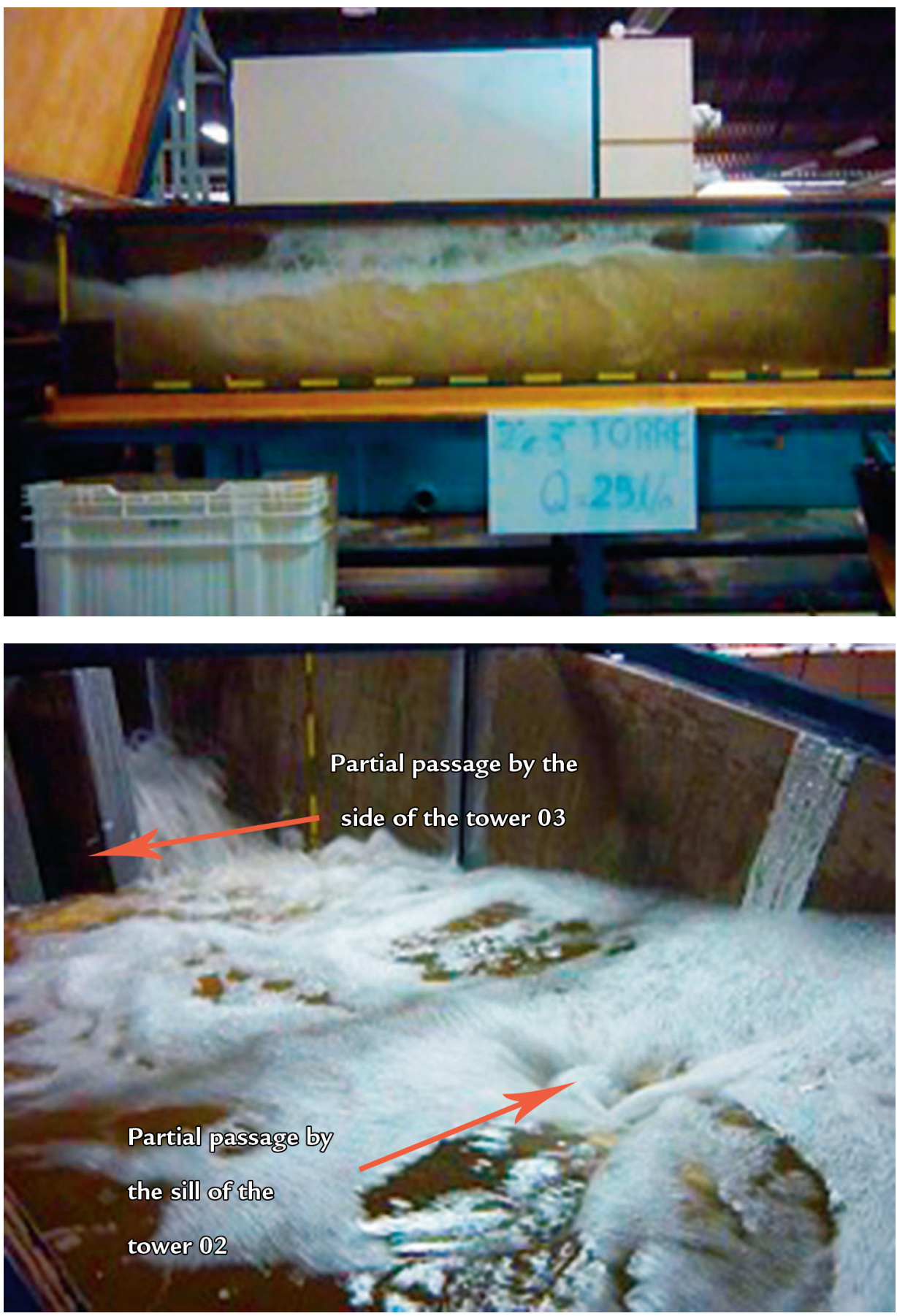

Table 3

Test battery for incoming flow through the downstream tower sill and the side of the upstream tower (subsequent).

sides are estimated from the flow depth measurements performed using a ruler installed in the reduced model structure.

Figure 8

Passage of ten thousand-year

floodwater (flow rate of $25 \mathrm{l} / \mathrm{s}$, corresponding to the model value), simultaneously through the sill of tower 02 and side of tower 03-view from the transition box.

Figure 9

Passage of ten thousand-year floodwater, simultaneously through the sill of tower 02 and side of tower 03 . 
Figure 10

Passage of ten

thousand-year floodwater, simultaneously by the sill of the tower 02 and the side of the tower 03 - view from the culvert.

\section{Discussion}

A comparison of analytical and experimental values of discharge flow on the tower sill and sides is performed using the results presented in Tables 2 and 3. The analytical flow estimates are based on the equation proposed by Azevedo Netto and Alvarez (1988) and Porto (1998).

Figure 11 presents the comparison of discharge curves resulting from tests in which the flow occurs only from the side of one tower, as shown in Table 2. It can be noted that the curves are parallel to each other and have good adherence to the theoretical discharge curve

Figure 11

Discharge curves for situation of flow through the lateral of water intake towers.

Figure 12

Discharge curves for the situation of the outflow through the sill of the downstream tower and through the side of the upstream tower (subsequent). determined in the design, according to Equation 6. The charge differences are about $0.10 \mathrm{~m}$. The analysis of Figure 12 also shows that tower 5 presented a slight lag result $(\cong 0,30 \mathrm{~m})$. We can explain this because of the proximity of the tower to the model's pipe flow supply. This proximity made the spill occur in a turbulent way, hindering the accurate reading of the water level inside the reservoir model.

Figure 12 shows a comparison of discharge curves resulting from tests in which the flow occurs through the tower sill and simultaneously through the side of the upstream tower (tests according to Table 3).

The results for towers 1 and 2 (as well as for towers 2 and 3 - which showed

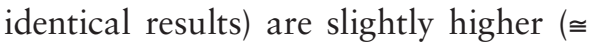
$0.05 \mathrm{~m}$ ) than the predicted design values (Eq. 6). Again, there is an exception presented by the outflow from towers 5 and 6, where the discharge curve became distanced from predicted values $(\cong 0.15$ $\mathrm{m}$ ) in design (Eq. 6). Also this fact can be explained by the proximity of the towers to the flow supply pipe of the model, as aforesaid.
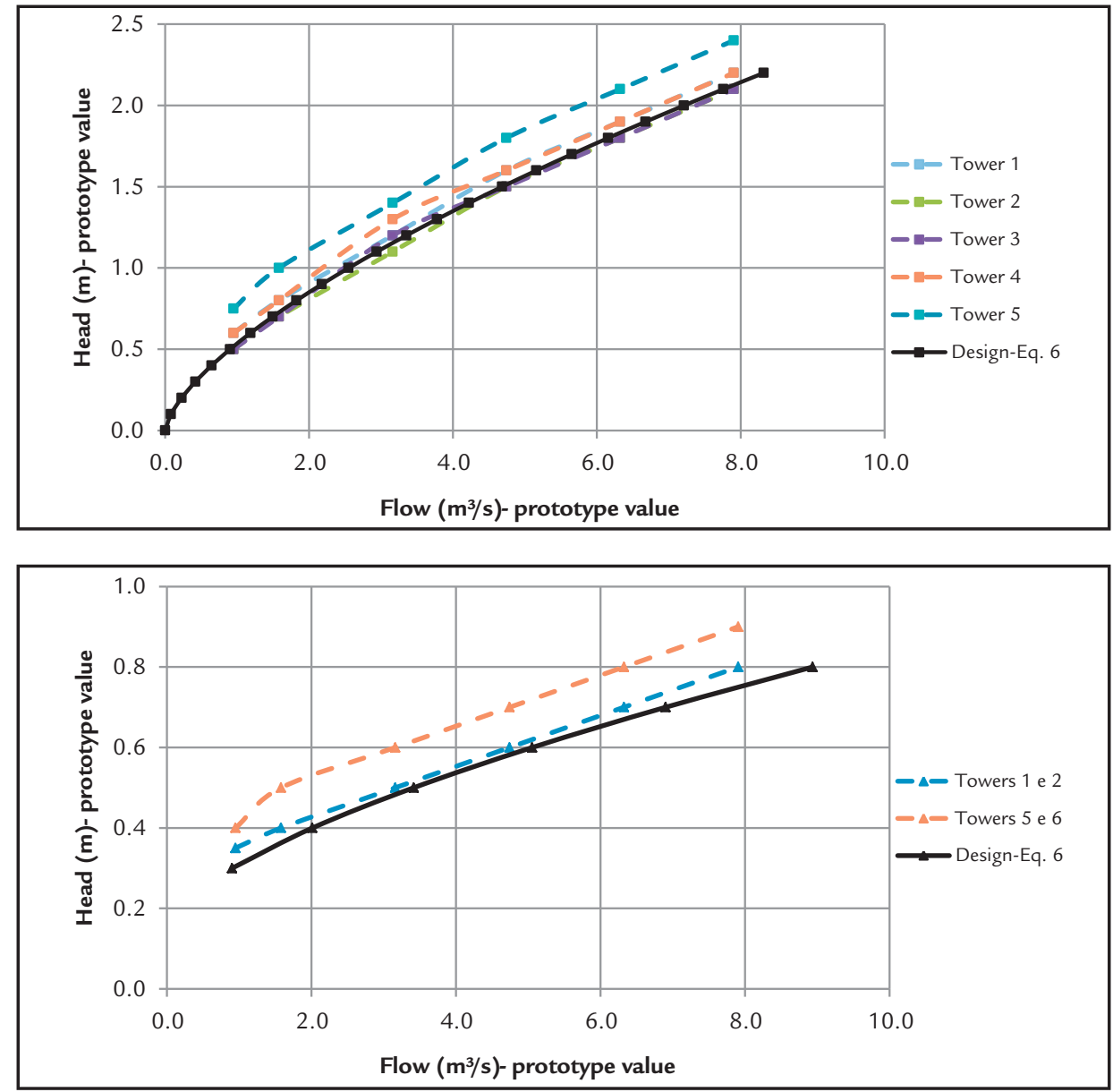
The average relative deviation of the values depicted by the discharge curves obtained from the hydraulic reduced model for the outflow operating system of Forquilha IV tailings dam in comparison with the values predicted by Eq. 6 for the prototype are within the range from $5 \%$ until $15 \%$ for both test experimental conditions, flow through the tower side (Figure 11) and flow through the sill of the tower (Figure 12).

The small values of relative deviation between the modeled experimental test results and the predictions from the classical equation (Eq. 6) indicate that this equation can be employed to render the basic dimensions of the outflow operating system of Forquilha IV tailings dam. However, in the preliminary design stages, it is highly recommended to perform studies using reduced models in order to estimate the discharge curves for different flow and operating conditions. Due to the fact that the dam crest (considering each proposed raising) is always higher than $5.0 \mathrm{~m}$ from the tower sill, we can state that the outflow operating system is capable of draining the design flow (ten thousandyear floodwater).

\section{Conclusions and recommendations}

According to the tests obtained from the reduced model of the outflow operating system in the Forquilha IV dam, we can state that it is able to drain the designed flow (Ten thousand-year floodwater recurrence), for situations anticipated operational (inlet flow only from the side of the towers or entry, concomitantly, the sill and side tower amount), ensuring building integrity.

Observation of the phenomena of water entrance in the structure, both through the sill and through the side of the tower, allows proposing changes to

\section{Acknowledgements}

The authors want to thank Vale S.A. and Vogbr Recursos Hídricos \& the design of the structure in order to reduce its dimensions, while maintaining its discharge capacity. This indicates the possibility of optimizing the structure by reducing installation costs. The results of this physical model allows for the preliminary hydraulic evaluation of similar structures, such as future operations of the Forquilha V (Mina de Fábrica, Ouro Preto/MG) and Fazenda Velha (Mining Complex Vargem Grand, Rio Acima/ MG) dams.

However, we recommend that the physical models be implemented in the early stages of design, because such studies are able to stimulate improvements for structures, such as decreasing insurance costs for project implementation.

In future investigations, pressure measurements on the hillside culvert and on the dissipation box as well as flow speed measurements can be performed in the model. With the measured pressure and velocity fields, it would be possible to obtain a reliable estimate for the hydraulic forces, which could be very useful for the structural design of the prototype.

\section{Bibliography}

Geotecnia S.A. for the transfer of study data on reduced hydraulic model as well as the executive design of Forquilha IV dam for this work.

ABNT. NBR 13028. Mineração - elaboração e apresentação de projeto de barragens para disposição de rejeitos, contenção de sedimentos e reservação de água, 2006. 6p.

AZEVEDO NETTO, J. M., Alvarez, G. A. Manual de Hidráulica. (7 ed.). São Paulo, 1988. v.1. $335 \mathrm{p}$.

CHOW, V. T. Open-channel hydraulics. New York, 1959. 680p.

COMITÊ BRASILEIRO DE BARRAGENS (CBDB). Barragens de Rejeitos no Brasil, 2012. 306p.

ESTADOS UNIDOS. Bureau of Reclamation (USBR). Design of small dams. 3rd ed. Denver: Government Printing Office, 1987. 860 p.

HAGER, W. H. Energy dissipators and hydraulic jump. Dordrecht: Kluwer Academic, 1992. $289 \mathrm{p}$.

LOPARDO, R. A. Apunte sobre fluctuaciones macroturbulentas de presión, medición, análisis y aplicación al resalto hidráulico. São Paulo: Escola Politécnica, 1986. 44p.

MATOS, J. Emulsionamento de ar e dissipação de energia do escoamento em descarregadores em degraus. Lisboa: Instituto Superior Técnico (IST), 1999. 357. (Tese de Doutorado).

OLIVEIRA, J. B. V. R. Manual de operação de barragens de contenção de rejeitos como requisito Essencial ao gerenciamento dos rejeitos e à segurança de barragens. Ouro Preto: Universidade Federal de Ouro Preto (UFOP), 2010. 150p. (Dissertação de Mestrado).

PORTO, R. M. Hidráulica básica. São Carlos: EESC/USP, , 1998. 519p.

SINNIGER, R.O., HAGER, W.H. Constructions Hydrauliques: Ecoulements stationnaires. Lausanne: presses polytechniques et universitaires Romandes, $1989.439 \mathrm{p}$.

TEIXEIRA, E. D. Efeito de escala na previsão dos valores extremos de pressão junto ao fundo em bacias de dissipação por ressalto bidráulico. Porto Alegre: - Instituto de Pesquisas Hidráulicas da Universidade Federal do Rio Grande do Sul (IPH/UFRGS), 2008. 178p. (Tese de Doutorado). 